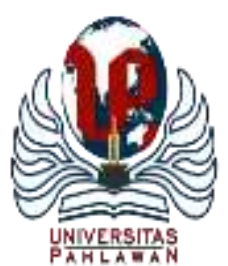

Edukatif : Jurnal Ilmu Pendidikan Volume 4 Nomor 1 Tahun 2022 Halm 1253 - 1262

EDUKATIF: JURNAL ILMU PENDIDIKAN

Research \& Learning in Education

https:/ledukatif.org/index.php/edukatif/index

\title{
Analisis Respon Pengguna terhadap Penerapan Web-based Assessment pada Penilaian Sikap Siswa terhadap Mata Pelajaran IPA dan Nilai-nilai Pendidikan Karakter
}

\author{
Febri Tia Aldila ${ }^{1 凶}$, Darmaji $^{2}$, Dwi Agus Kurniawan ${ }^{3}$ \\ Program Studi Pendidikan Fisika, Universitas Jambi, Indonesia ${ }^{1,2,3}$ \\ E-mail : febritia92@ gmail.com ${ }^{1}, \underline{\text { darmaji@unja.ac.id }}^{2}$, dwiagus.k@unja.ac.id $^{3}$
}

\begin{abstract}
Abstrak
Penelitian ini bertujuan untuk mengukur dan mengetahui respon pengguna (siswa) terhadap penerapan webbased assessment untuk melakukan penilaian sikap siswa terhadap mata pelajaran IPA dan nilai-nilai pendidikan karakter. Penelitian ini merupakan penelitian dengan metode mixed method dengan data kuantitatif dianalisis dengan statistik deskriptif dan data kualitatif dianalisis dengan teknik Miles and Huberman.Data dalam penelitian ini diperoleh dengan menggunakan angket respon pengguna (siswa) dan lembar wawancara. Subjek dalam penelitian ini adalah siswa SMPN 6 Batang Hari yang melakukan pembelajaran IPA. Hasil analisis data menunjukkan bahwa rata-rata respon pengguna yang diperoleh adalah sebesar 3.38 yang berada dalam kategori sangat baik. Hal tersebut menunjukkan bahwa siswa memiliki respon yang baik terhadap peggunakan web-based assessment dalam pelaksanaan penilaian sikap siswa terhadap mata pelajaran IPA dan nilai-nilai pendidikan karakter. Penggunaan web-based assessment dalam penilaian sikap siswa terhadap mata pelajaran IPA dan nilai-nilai karakter memiliki banyak keunggulan antara lain hemat biaya pengadaan, efisiensi waktu dalam pengolahan data, dan mudah untuk digunakan.
\end{abstract}

Kata Kunci: web-based assessment, sikap, karakter, sains.

\begin{abstract}
This study aims to measure and determine user (student) responses to the application of web-based assessment to assess student attitudes towards science subjects and character education values. This study is a mixed method research with quantitative data analyzed by descriptive statistics and qualitative data analyzed by the Miles and Huberman technique. The data in this study were obtained using user (student) response questionnaires and interview sheets. The subjects in this study were students of SMPN 6 Batang Hari who did science lessons. The results of data analysis show that the average user response obtained is 3.38 which is in the very good category. This shows that students have a good response to the use of web-based assessment in the implementation of the assessment of student attitudes towards science subjects and character education values. The use of web-based assessment in assessing student attitudes towards science subjects and character values has many advantages, including cost-effective procurement, time efficiency in data processing, and easy to use.
\end{abstract}

Keywords: web-based assessment, attitude, character, science

Copyright (c) 2022 Febri Tia Aldila, Darmaji, Dwi Agus Kurniawan

$\triangle$ Corresponding author

Email : febritia92@gmail.com

DOI : https://doi.org/10.31004/edukatif.v4i1.2091

ISSN 2656-8063 (Media Cetak)

ISSN 2656-8071 (Media Online)

Edukatif : Jurnal Ilmu Pendidikan Vol 4 No 1 Tahun 2022 p-ISSN 2656-8063 e-ISSN 2656-8071 
1254 Analisis Respon Pengguna terhadap Penerapan Web-based Assessment pada Penilaian Sikap Siswa terhadap Mata Pelajaran IPA dan Nilai-nilai Pendidikan Karakter - Febri Tia Aldila, Darmaji, Dwi Agus Kurniawan

DOI: https://doi.org/10.31004/edukatif.v4i1.2091

\section{PENDAHULUAN}

Perkembangan ilmu pengetahuan dan teknologi yang terjadi sangat pesat dan dinamis akan berdampak pada segala bidang kehidupan manusia (Airlanda, 2018; Cholik, 2017; Lin et al., 2019). Kemajuan teknologi yang terjadi akan berkembang sesuai dengan kemajuan ilmu pengetahuan sehingga akan sangat berguna dalam pembelajaran (Garcia et al., 2020; Jamun, 2018; Kola, 2017). Perkembangan teknologi akan berpengaruh tehadap dunia pendidikan khususnya dalam mengembangkan kompetensi peningkatan sumber daya manusia guna mewujudkan keberhasilan pendidikan (Budiman, 2017; Darmaji et al., 2020). Pemanfaatan teknologi dalam pendidikan akan meningkatkan kualitas kegiatan pembelajaran karena mampu menciptakan kegiatan pembelajaran yang inovatif (Mardiana, 2020; Suma et al., 2020). Pemanfaatan teknologi dapat digunakan dalam pembelajaran IPA.

Pembelajaran IPA merupakan salah satu pembelajaran pada kurikulum 2013 yang mempelajari hal bersifat empiris dan eksakta yang memiliki konsep kajian sains yang diperoleh melalui serangkaian metode ilmiah (Kurniawan, Astalini, Kurniawan, et al., 2019; Maison et al., 2020; Susilowati, 2017). Pembelajaran sains disusun dengan mempertanyakan fenomena alam dan sosial siswa yang disajikan dalam bentuk pengetahuan konsep berbasis masalah sebagai titik awal penyelidikan ilmiah (Anisa, 2017; Kang \& Noh, 2017; Sadiqin et al., 2017). Pembelajaran sains diterapkan dengan prinsip umum yang berlaku dalam memahami hakikat IPA yang dikaitkan dengan kegiatan sehari-hari (Harlen \& Qualter, 2018; Pamungkas et al., 2017). Terdapat tiga domain nilai dalam masyarakat yaitu nilai-nilai pendidikan, nilai-nilai sains, dan nilai-nilai pendidikan sains yang memiliki perbedaan sehingga dengan adanya kurikulum pendidikan sains yang kuat, evaluasi (penilaian) siswa terhadap sains sangat dibutuhkan (Diamond, 2020). Penilaian yang dilakukan oleh pendidik meliputi tiga aspek yaitu aspek sikap, pengetahuan, dan keterampilan dimana penilaian sikap dilakukan untuk memperoleh informasi yang mendeskripsikan perilaku peserta didik (Ahmad, 2020).

Ranah afektif berupa sikap dan karakter siswa dalam pembelajaran IPA sangat penting untuk diperhatikan lebih dalam. Sikap yang ditunjukkan oleh siswa dalam pembelajaran IPA merupakan sikap siswa terhadap mata pelajaran IPA. Sikap siswa terhadap mata pelajaran IPA mampu menganalisis respon siswa terhadap pembelajaran IPA berupa sikap positif ataupun sikap negatif (Kurniawan, Astalini, \& Kurniawan, 2019a, 2019b; Kurniawan et al., 2019). Sikap siswa terhadap mata pelajaran IPA sangat menentukan keberhasilan proses pembelajaran (Astalini et al., 2019). Astalini \& Kurniawan, (2019) menyatakan bahwa sikap siswa terhadap mata pelajaran IPA memiliki 7 indikator yaitu 1) implikasi sosial dari IPA, 2) normalitas ilmuwan, 3) sikap terhadap penyelidikan IPA, 4) adaptasi dari sikap ilmiah, 5) kesenangan dalam belajar IPA, 6) ketertarikan memperbanyak waktu belajar IPA, 7) ketertarikan berkarir dalam IPA.

Karakter siswa harus ditingkatkan dengan penanaman nilai-nilai Pancasila (Purnama, 2015; Rockenbach, 2020). Penguatan karakter siswa menjadi langkah dalam mewujudkan tujuan pendidikan nasional karena merupakan cerminan karakter bangsa (Astuti \& Mufrihah, 2019; Permata \& Mustadi, 2020). Karakter siswa memiliki nilai-nilai yang beragam. Kemendiknas, (2010) menyatakan bahwa terdapat 18 nilainilai pendidikan karakter yaitu 1) religius, 2) jujur, 3) toleransi, 4) disiplin, 5) kerja keras, 6) kreatif, 7) mandiri, 8) demokratis, 9) rasa ingin tahu, 10) semangat kebangsaan, 11) cinta tanah air, 12) menghargai prestasi, 13) bersahabat/komunikatif, 14) cinta damai, 15) gemar membaca, 16) peduli lingkungan, 17) peduli sosial, 18) tanggung jawab.

Penilaian terhadap sikap siswa terhadap mata pelajaran IPA dan nilai-nilai pendidikan karakter sangat dibutuhkan dalam pembelajaran IPA. Penilaian karakter siswa didefinisikan sebagai penilaian sikap dan karakter siswa yang dilakukan secara konsisten sehingga memegang peranan yang sangat penting (Astalini dkk., 2019). Tiara \& Sari (2019) mengemukakan bahwa penilaian sikap dan karakter siswa digunakan untuk 
1255 Analisis Respon Pengguna terhadap Penerapan Web-based Assessment pada Penilaian Sikap Siswa terhadap Mata Pelajaran IPA dan Nilai-nilai Pendidikan Karakter - Febri Tia Aldila, Darmaji, Dwi Agus Kurniawan

DOI: https://doi.org/10.31004/edukatif.v4i1.2091

menganalisis sikap dan karakter pada diri siswa yang diperoleh dari pembelajaran. Pendidikan karakter dapat ditanamkan melalui berbagai keadaan, baik dari kegiatan akademik, pengembangan diri, hingga hal yang bersifat spontanitas (Fajriah \& Anggereini, 2016). Pendidikan karakter tertanam dalam seluruh proses belajar mengajar, mulai dari kurikulum hingga di kelas (Suhartini et al., 2019).

Salah satu bentuk penilaian yang berbasis pada teknologi dikenal dengan e-assessment. E-assessment yang banyak digunakan adalah web-based assessment. Web-based assessment sudah banyak digunakan saat ini dan menggantikan penilaian berbasis kertas (Astalini, Darmaji, Kurniawan, Anwar, et al., 2019; Liu et al., 2017). Sistem penilaian elektronik khususnya web-based assessment dapat memfasilitasi penilaian dalam skala yang lebih luas (Dhina et al., 2021; Zheng et al., 2017). Web-based assessment yang digunakan sebagai media penilaian memiliki keunggulan yaitu mampu memberikan umpan balik dengan cepat ataupun realtime dan mampu menunjukan letak kesalahan siswa dengan cepat (Ediyanto, 2016).

Berdasarkan hasil analisis dokumen pada repositori Universitas Jambi dan lainnya dapat disimpulkan bahwa 1) penilaian sikap siswa terhadap mata pelajaran IPA dan nilai-nilai pendidikan karakter masih menggunakan penilaian berbasis cetak, 2) pengolahan data menggunakan Ms. Excel dan SPSS dimana harus memindahkan data dari angket ke komputer sehingga hasil penilaian tidak dapat diketahui segera, 3) instrumen berbasis cetak membutuhkan biaya besar dalam pengadaan angket. Kemudian berdasarkan observasi awal yang dilakukan dengan guru mata pelajaran IPA di SMPN 6 Batang Hari menunjukkan bahwa guru mata pelajaran melakukan penilaian terhadap ranah afektif siswa dengan instrumen cetak atau menggunakan kertas.

Penerapan web-based assessment untuk mengukur sikap siswa terhadap mata pelajaran IPA dan nilainilai pendidikan karakter di SMPN 8 Batang Hari menimbulkan beberapa respon dari pengguna. Kepuasan atau ketidakpuasan pengguna adalah gambaran pengamatan siswa terhadap objek yang telah diamati. Respon pengguna menjadi hal yang penting dalam penerapan suatu produk karena menjadi faktor penentu keberhasilan suatu produk. Berdasarkan latar belakang di atas, maka tujuan dari penelitian ini adalah untuk mengetahui bagaimana respon pengguna terhadap penerapan web-based assessment untuk mengukur sikap siswa terhadap mata pelajaran IPA dan nilai-nilai pendidikan karakter.

\section{METODE PENELITIAN}

Penelitian ini merupakan penelitian mixed methods dengan desain eksplanatori. Desain eksplanatori digunakan untuk menguji hipotesis antar-variabel dan diawali dengan kegiatan identifikasi masalah, kemudian dilanjutkan dengan membuat rumusan masalah (ilmiah) (Hendarawan, 2020). Subjek penelitian dalam penelitian ini adalah siswa aktif di SMPN 6 Batang Hari yang sedang melakukan pembelajaran IPA yang diperoleh dengan teknik purposive sampling.

Pengambilan data dilakukan pada tanggal 2 Desember 2021 di SMPN 6 Batanghari. Data dikumpulkan dengan menggunakan angket respon pengguna yang dalam hal ini pengguna merupakan siswa SMPN 6 Batanghari. Angket respon pengguna diadaptasi dari penelitian Pratama \& Buditjahjanto (2016) yang terdiri dari 30 pernyataan dengan kisi-kisi dapat dilihat pada Tabel 1 di bawah ini.

Tabel 1. Hasil Statistik Deskritif

\begin{tabular}{clll}
\hline Variabel & \multicolumn{1}{c}{ Indikator } & Item \\
\hline Materi & 1. Pemilihan warna huruf. & 1,2 & \\
& 2. Penilaian ukuran huruf. & 3,4 \\
& 3. Kesesuaian ukuran grafik. & 6 & \\
& 4. Kejelasan grafik. & $7,8,9$ & \\
\hline
\end{tabular}


1256 Analisis Respon Pengguna terhadap Penerapan Web-based Assessment pada Penilaian Sikap Siswa terhadap Mata Pelajaran IPA dan Nilai-nilai Pendidikan Karakter - Febri Tia Aldila, Darmaji, Dwi Agus Kurniawan

DOI: https://doi.org/10.31004/edukatif.v4i1.2091

\begin{tabular}{cll}
\hline Bahasa & 1. Bahasa yang digunakan mudah dipahami. & $5,10,11$ \\
& 2. Tata bahasa yang digunakan sesuai EYD & 12,18 \\
\hline \multirow{2}{*}{ Tampilan } & 1. Kemudahan penggunaan media. & $13,14,19,25,26,27,28,29,30$ \\
& 2. Tampilan media menarik. & $15,16,17$ \\
\hline \multirow{2}{*}{ Manfaat } & 1. Media memberikan informasi penilaian karakter siswa & $21,22,23$ \\
& 2. Mempermudah guru untuk menilai karakter siswa. & 20,24 \\
\hline
\end{tabular}

Angket respon pengguna menggunakan skala likert dengan skor 4 untuk kategori sangat baik (SB), skor 3 untuk kategori baik (B), skor 2 untuk kategori tidak baik (TB), dan skor 1 untuk kategori sangat tidak baik (STB). Kategori respon pengguna terhadap penerapan web-based assessment untuk mengukur sikap siswa terhadap mata pelajaran IPA dan nilai-nilai pendidikan karakter dapat dilihat pada Tabel 2.

Tabel 2. Kategori Respon Pengguna

\begin{tabular}{ccl}
\hline Rentang & Skor & \multicolumn{1}{c}{ Kategori } \\
\hline $1,00-1,75$ & 1 & Sangat Tidak Baik (STB) \\
\hline $1,76-2,50$ & 2 & Tidak Baik (TB) \\
\hline $2,51-3,25$ & 3 & Baik (B) \\
\hline $3,26-4,00$ & 4 & Sangat Baik (SB) \\
\hline
\end{tabular}

Teknik pengolahan data respon pengguna dilakukan dengan menggunakan statistik deskriptif. Statistik deskriptif berhubungan dengan hal menguraikan atau memberikan keterangan-keterangan mengenai suatu data atau keadaan atau fenomena (Nasution, 2017). Adapun hasil wawancara dianalisis dengan teknik Miles \& Huberman. Wawancara yang digunakan dalam penelitian ini merupakan wawancara dengan tipe pertanyaan terbuka dan terstruktur. Peneliti mengajukan beberapa pertanyaan untuk mempelajari lebih lanjut tentang tanggapan responden terkait penerapan web-based assessment dalam penilaian sikap siswa terhadap mata pelajaran IPA dan nilai-nilai pendidikan karakter. Hasil wawancara diharapkan untuk memperkuat hasil respon pengguna yang dikumpulkan melalui angket.

\section{HASIL DAN PEMBAHASAN PENELITIAN}

Web-based assessment memiliki banyak kelebihan dibandingkan penilaian berbasis kertas sehingga menjadi inovasi beru dalam proses penilaian. Oleh sebab itu, web-based assessment sangat diperlukan dalam mengukur sikap siswa terhadap mata pelajaran IPA dan nilai-nilai pendidikan karakter dalam pembelajaran IPA. Deskripsi respon pengguna terhadap pemanfaatan web-based assessment untuk mengukur sikap siswa terhadap mata pelajaran IPA dan nilai-nilai pendidikan karakter dapat dilihat pada Tabel 3.

Tabel 3. Deskripsi Statistik Respon Pengguna

\begin{tabular}{|c|c|c|c|c|c|c|c|c|}
\hline Interval & f & $\%$ & Kategori & Mean & Me & Mo & Max & Min \\
\hline $1,00-1,75$ & 0 & $0 \%$ & Sangat Tidak Baik & \multirow{4}{*}{3,38} & \multirow{4}{*}{3,46} & \multirow{4}{*}{3,47} & \multirow{4}{*}{3,80} & \multirow{4}{*}{2,97} \\
\hline $1,76-2,50$ & 0 & $0 \%$ & Tidak Baik & & & & & \\
\hline $2,51-3,25$ & 6 & $30 \%$ & Baik & & & & & \\
\hline $3,26-4,00$ & 14 & $70 \%$ & Sangat Baik & & & & & \\
\hline
\end{tabular}

Tabel 3 menunjukkan hasil respon siswa terhadap instrumen penerapan web-based assessment untuk mengukur sikap siswa terhadap mata pelajaran IPA dan nilai-nilai pendidikan karakter. Berdasarkan tabel tersebut, perolehan skor angka dari 20 responden dengan menghasilkan data yang valid untuk nilai minimumnya adalah 2,97 dan nilai maksimum 3,80, rata-rata sebesar 3,38, median sebesar 3,46, dan modus 
1257 Analisis Respon Pengguna terhadap Penerapan Web-based Assessment pada Penilaian Sikap Siswa terhadap Mata Pelajaran IPA dan Nilai-nilai Pendidikan Karakter - Febri Tia Aldila, Darmaji, Dwi Agus Kurniawan

DOI: https://doi.org/10.31004/edukatif.v4i1.2091

sebesar 3,47. Berdasarkan jumlah persentase respon pengguna diperoleh $30 \%$ pengguna memiliki respon yang baik terhadap instrumen penerapan web-based assessment untuk mengukur sikap siswa terhadap mata pelajaran IPA dan nilai-nilai pendidikan karakter. Adapun sebanyak $70 \%$ dari pengguna memiliki respon yang sangat baik terhadap instrumen penerapan web-based assessment untuk mengukur sikap siswa terhadap mata pelajaran IPA dan nilai-nilai pendidikan karakter.

Instrumen respon pengguna yang digunakan terdiri atas empat indikator penilaian, yaitu penilaian materi, bahasa, tampilan, dan manfaat. Berdasarkan data yang telah dianalisis maka diperoleh persentase untuk setiap indikator ditunjukkan oleh Tabel 4 di bawah ini.

Tabel 4. Hasil Penilaian Penerapan Web-Based Assessment

\begin{tabular}{cccccc}
\hline \multirow{2}{*}{ Indikator } & \multirow{2}{*}{ Rerata } & \multicolumn{4}{c}{ Kategori } \\
\cline { 3 - 5 } & & STB (\%) & TB (\%) & B (\%) & SB (\%) \\
\hline Materi & 3,43 & $0 \%$ & $0 \%$ & $40 \%$ & $60 \%$ \\
\hline Bahasa & 3,46 & $0 \%$ & $0 \%$ & $35 \%$ & $65 \%$ \\
\hline Tampilan & 3,36 & $0 \%$ & $0 \%$ & $40 \%$ & $60 \%$ \\
\hline Manfaat & 3,30 & $0 \%$ & $10 \%$ & $40 \%$ & $50 \%$ \\
\hline
\end{tabular}

Berdasarkan Tabel 4 pada indikator materi yang menilai tentang pemilihan warna, grafik, dan huruf diperoleh rata-rata respon pengguna sebesar 3,43 dengan $40 \%$ berada di kategori baik dan $60 \%$ berada di kategori sangat baik. Pada indikator bahasa yang memuat penilaian terhadap susunan bahasa diperoleh ratarata respon pengguna sebesar 3,46 dengan 35\% berada di kategori baik dan 65\% berada di kategori sangat baik. Pada indikator tampilan yang memuat penilaian terhadap tampilan web dan kemudahan pengoperasian web diperoleh rerata respon pengguna sebesar 3,36 dengan $40 \%$ berada di kategori baik dan $60 \%$ berada di kategori sangat baik.

Pada indikator manfaat diperoleh rerata respon pengguna sebesar 3,30 dengan $10 \%$ berada di kategori tidak baik, $40 \%$ berada di kategori baik dan $50 \%$ berada di kategori sangat baik. Berdasarkan respon tersebut dapat disimpulkan bahwa pengguna memiliki respon yang sangat baik terhadap penerapan web-based assessment untuk mengukur sikap siswa terhadap mata pelajaran IPA dan nilai-nilai pendidikan karakter. Pada indikator materi, bahasa, tampilan, dan manfaat berada pada kategori sangat baik. Oleh sebab itu, web-based assessment yang diterapkan untuk mengukur sikap siswa terhadap mata pelajaran IPA dan nilai-nilai pendidikan karakter sudah sangat baik diterapkan pada pembelajaran IPA.

Selanjutnya, hasil wawancara menunjukkan bahwa pengguna mendukung web-based assessment untuk mengukur sikap siswa terhadap mata pelajaran IPA dan nilai-nilai pendidikan karakter, karena dengan penggunaan penilaian berbasis web lebih efisien dan memiliki beberapa kelebihan. Hasil wawancara dapat ditunjukkan sebagai berikut.

- "Saya sangat suka dengan tampilan web yang menarik dan praktis untuk digunakan."

- "Penerapan web-based assessment yang digunakan untuk mengukur sikap siswa terhadap mata pelajaran IPA dan nilai-nilai pendidikan karakter sangat membantu proses penilaian karena memberikan hasil olah data yang sangat detail dan real time."

- "Penggunaan web-based assessment membuat saya menjadi tertarik dalam mengisi angket dan sangat memudahkan saya dalam memasukkan data."

- "Saya suka ide penilaian berbasis web karena dapat diakses melalui perangkat seluler daripada penilaian konvensional yang menggunakan kertas karena tidak perlu lagi mencetak lembar penilaian setiap melakukan penilaian."

- "Penggunaan penilaian berbasis web sangat efisien karena tidak menggunakan kertas lagi yang kurang praktis." 
1258 Analisis Respon Pengguna terhadap Penerapan Web-based Assessment pada Penilaian Sikap Siswa terhadap Mata Pelajaran IPA dan Nilai-nilai Pendidikan Karakter - Febri Tia Aldila, Darmaji, Dwi Agus Kurniawan

DOI: https://doi.org/10.31004/edukatif.v4i1.2091

Berdasarkan hasil wawancara yang telah dilakukan dapat disimpulkan bahwa responden memberikan respon yang positif terkait penerapan e-assessment dalam melakukan penilaian karakter. Responden menyebutkan bahwa penggunaan penilaian berbasis web lebih efisien dari segi waktu dengan alasan cepat dalam mengolah data, cepat dalam mendistribusikan data, dan mengorganisasikan data karena tidak memerlukan kertas lagi. Hal ini sejalan dengan hasil penelitian yang dilakukan oleh Appiah \& Tonder, (2018), bahwa ada banyak manfaat dari e-assessment baik digunakan untuk tujuan formatif atau sumatif yang dapat dilakukan dalam jangka waktu tertentu terutama jika jawaban siswa ditandai secara otomatis.

Penilaian berbasis web (web-based assessment) memiliki banyak keuntungan dibandingkan dengan penilaian berbasis kertas. Web-based assessment menyediakan umpan balik dalam proses penilaian (Astalini et al., 2019). Hal tersebut sejalan dengan Wang, (2011) bahwa web-based assessment memberikan umpan balik yang dapat diterima secara langsung oleh peserta didik. Selain itu, penilaian online mampu menampung penilaian dalam jumlah yang banyak. Sejalan dengan Bahar \& Asil, (2018) yang mengemukakan bahwa webbased assessment dapat mencakup penilaian dalam jumlah yang besar dan dalam waktu yang bersamaan. Penggunaan penilaian berbasis web akan memungkinkan siwa untuk menerima informasis secara lansgung sehingga sangat efisien untuk digunakan (Wang, 2018).

Penggunaan penilaian berbasis web akan memunculkan respon pengguna terhadap penerapan web tersebut. Respon pengguna terhadap web-based assessment untuk mengukur sikap siswa terhadap mata pelajaran IPA dan nilai-nilai pendidikan karakter dapat menunjukkan hasil bagaimana website digunakan dalam proses penilaian. Penilaian sikap siswa terhadap mata pelajaran IPA dan nilai-nilai pendidikan karakter berbasis website dapat meningkatkan minat belajar siswa. Penggunaan website dapat melatih kemandirian dan keaktifan siswa secara online untuk menunjang proses pembelajaran sehingga menghasilkan sikap positif siswa dalam belajar. Selain itu, penelitian tentang respon siswa terhadap penilaian sikap siswa terhadap mata pelajaran IPA dan nilai-nilai pendidikan karakter juga akan membuat proses penilaian menjadi lebih kompleks. Hal ini sesuai dengan penelitian Akkaya, (2016), yang menunjukkan bahwa menggabungkan pengetahuan teknologi dan pedagogis akan mengembangkan respon siswa terhadap pembelajaran.

Penelitian tentang respon pengguna telah banyak dilakukan oleh peneliti sebelumnya. Ditemukan bahwa siswa memiliki respon pengguna yang baik pada penerapan web-based assessment untuk mengukur keterampilan proses sains (Winda et al., 2021). Hal tersebut ditunjukkan dengan responden yang mengemukakan bahwa penilaian berbasis web menjadikan kegiatan penilaian lebih variatif dan mudah untuk digunakan. Selain itu, penilaian ranah afektif siswa yang dilakukan dengan penilaian berbasis website dapat meningkatkan minat belajar siswa (Darmaji et al., 2021). Oleh sebab itu, penggunaan web-based assessment mampu membuat penilaian lebih inovatif dan menjadikan siswa lebih tertarik dan berminat dalam pembelajaran IPA. Astalini et al., (2019) mengemukakan pengembangan e-assessment untuk menilai sikap dan karakter siswa perlu untuk terus dilakukan secara efektif dan efisien karena dapat digunakan dari jarak jauh dan interaktif.

Berdasarkan penelitian yang telah dilakukan menunjukkan bahwa pengembangan web-based assessment sangat diperlukan dalam mengukur sikap dan karakter siswa. Kemudian, setelah pengembangan dilaksanakan maka kajian respon pengguna juga sangat dibutuhkan guna mengetahui bagaimanakah respon atau tanggapan pengguna terhadap website yang dikembangkan. Kajian respon pengguna terhadap penerapan web-based assessment untuk mengukur sikap siswa terhadap mata pelajaran IPA dan nilai-nilai pendidikan karakter belum ada dilakukan oleh peneliti sebelumnya. Oleh karena itu, hal baru dalam penelitian ini adalah untuk mengkaji respon pengguna terhadap penerapan web-based assessment untuk mengukur sikap siswa terhadap mata pelajaran IPA dan nilai-nilai pendidikan karakter.

Kebaruan dalam penelitian ini adalah untuk mengkaji respon pengguna terhadap penerapan web-based assessment untuk mengukur sikap siswa terhadap mata pelajaran IPA dan nilai-nilai pendidikan karakter. 
1259 Analisis Respon Pengguna terhadap Penerapan Web-based Assessment pada Penilaian Sikap Siswa terhadap Mata Pelajaran IPA dan Nilai-nilai Pendidikan Karakter - Febri Tia Aldila, Darmaji, Dwi Agus Kurniawan

DOI: https://doi.org/10.31004/edukatif.v4i1.2091

Penelitian sebelumnya membahas tentang pengembangan web-based assessment, dan persepsi siswa terhadap web-based assessment. Analisis respon pengguna khususnya dalam penggunaan web-based assessment yang digunakan untuk mengukur sikap siswa terhadap mata pelajaran IPA dan nilai-nilai pendidikan karakter belum dilakukan. Oleh sebab itu, penelitian ini akan melengkapi hal tersebut.

Penilaian sikap siswa terhadap mata pelajaran IPA dan nilai-nilai pendidikan karakter berbasis web juga memudahkan guru karena tidak perlu mengoreksi jawaban siswa secara manual, sehingga proses penilaian jauh lebih efektif dan efisien. Penelitian ini bertujuan untuk mengetahui respon pengguna yaitu siswa terhadap penerapan penilaian sikap siswa terhadap mata pelajaran IPA dan nilai-nilai pendidikan karakter berbasis web dalam pembelajaran IPA. Guru diharapkan mampu menghadapi perkembangan teknologi dengan menggunakan penilaian berbasis teknologi sehingga lebih efektif dan efisien dalam penggunaannya. Sehingga penelitian ini diharapkan dapat digunakan sebagai dasar untuk mengembangkan proses penilaian berbasis teknologi untuk mendukung terselenggaranya proses pembelajaran yang lebih baik.

\section{KESIMPULAN}

Berdasarkan hasil penelitian yang telah dilakukan maka dapat disimpulkan bahwa pengguna (siswa) memiliki respon yang sangat baik terhadap penerapan web-based assessment yang digunakan untuk mengukur sikap siswa terhadap mata pelajaran IPA dan nilai-nilai pendidikan karakter. Pengguna (siswa) dalam wawancara memberikan alasan yang menginformasikan bahwa penilaian berbasis web untuk mengukur sikap siswa terhadap mata pelajaran IPA dan nilai-nilai pendidikan karakter memiliki banyak keunggulan yaitu kemudahan dalam mengoperasikannya, efisiensi waktu dalam mengolah data, dan dapat di akses kapan pun dalam jumlah yang besar.

\section{DAFTAR PUSTAKA}

Ahmad, I. F. (2020). Alternative Assessment In Distance Learning In Emergencies Spread Of Coronavirus Disease (Covid-19) In Indonesia. Jurnal Pedagogik, 7(1), 195-222. Https://Ejournal.Unuja.Ac.Id/Index.Php/Pedagogik

Airlanda, G. S. (2018). The Analysis Of Scientific Attitude With Environmental Knowledge Through The Role Of Teacher And Parents. Jurnal Pendidikan Indonesia, 7(2), 130-136.

Anisa, A. (2017). Meningkatkan Keterampilan Berpikir Kritis Peserta Didik Melalui Pembelajaran Ipa Berbasis Potensi Lokal Jepara. Jurnal Inovasi Pendidikan Ipa, 3(1), 1-11. Https://Doi.Org/10.21831/Jipi.V3i1.8607

Astalini, A., Darmaji, D., Kurniawan, D. A., Anggraini, L., \& Perdana, R. (2019). E-Assessment On Student's Self-Concept For Physics Learning. Jurnal Ilmu Pendidikan, 25(2), 73-81. Https://Doi.Org/10.17977/Um048v25i2p73-81

Astalini, A., Darmaji, D., Kurniawan, D. A., \& Destianti, A. (2019). Description Of The Dimensions Attitudes Towards Science In Junior High School At Muaro Jambi. International Journal Of Sciences: Basic And Applied Research (Ijsbar), 47(1), 1-11.

Astalini, A., Darmaji, D., Kurniawan, W., Anwar, K., \& Kurniawan, D. A. (2019). Effectiveness Of Using EModule And E-Assessment. International Journal Of Interactive Mobile Technologies, 13(9), 21-39. Https://Doi.Org/Https://Doi.Org/10.3991//jim.V13i09.11016

Astalini, A., \& Kurniawan, D. A. (2019). Pengembangan Instrumen Sikap Siswa Sekolah Menengah Pertama Terhadap Mata Pelajaran Ipa. Jurnal Pendidikan Sains, 7(1), $1-7$.

Astuti, B., \& Mufrihah, A. (2019). Arrangment Of Responsibility Character Module Using Expert Validation. 
1260 Analisis Respon Pengguna terhadap Penerapan Web-based Assessment pada Penilaian Sikap Siswa terhadap Mata Pelajaran IPA dan Nilai-nilai Pendidikan Karakter - Febri Tia Aldila, Darmaji, Dwi Agus Kurniawan

DOI: https://doi.org/10.31004/edukatif.v4i1.2091

Journal Of Education And Learning (Edulearn), 13(3), 402-409. Https://Doi.Org/Https://Doi.Org/10.11591/Edulearn.V13i3.9808

Bahar, M., \& Asil, M. (2018). Attitude Towards E-Assessment: Influence Of Gender, Computer Usage And Level Of Education. Open $\quad$ Learning, $1-17$. Https://Doi.Org/Https://Doi.Org/10.1080/02680513.2018.1503529

Budiman, H. (2017). Peran Teknologi Informasi Dan Komunikasi Dalam Pendidikan. Al-Tadzkiyyah: Jurnal Pendidikan Islam, 8(1), 31-43. Https://Doi.Org/10.24042/Atjpi.V8i1.2095

Cholik, C. A. (2017). Pemanfaatan Tik Untuk Meningkatkan Pendidikan Di Indonesia. Jurnal Ilmiah Indonesia, 2(6), 21-29.

Darmaji, Astalini, Kurniawan, D. A., \& Aldila, F. T. (2021). Students' Perceptions In The Use Of Web-Based Character Assessment: A View From Gender Perspective. Jurnal Pendidikan Progresif, 11(2), 362-383. Https://Doi.Org/10.23960/Jpp.V

Darmaji, Kurniawan, D. A., Astalini, Winda, F. R., Heldalia, \& Kartina, L. (2020). The Correlation Between Student Perceptions Of The Use Of E- Modules With Students' Basic Science Process Skills. Jurnal Pendidikan Indonesia, 9(4), 719-729. Https://Doi.Org/Http://Dx.Doi.Org/10.23887/JpiUndiksha.V9i4.28310

Dhina, M. A., Hadisoebroto, G., Mubaroq, S. R., \& Gustiana, I. (2021). Implementation Of Digital Performance Assessment To Measure Pharmacy Physics Laboratory Skills. Momentum: Physics Education Journal, 5(1), 65-72. Https://Doi.Org/Https://Doi.Org/10.21067/Mpej.V5i1.5146

Diamond, A. H. (2020). The Social Reproduction Of Science Education Outcomes For High School Students In Israel. British Journal Of Sociology Of Education, 41(7), 1-18. Https://Doi.Org/10.1080/01425692.2020.1806040

Ediyanto. (2016). Siklus Prapembelajaran Model Penilaian Formatif Web-Based Pada Pembelajaran Fisika Materi Suhu Dan Kalor Untuk Siswa Smk Kelas X. Jurnal Pendidikan Fisika Indonesia, 12(2), 126136. Https://Doi.Org/10.15294/Jpfi.V12i2.5906

Fajriah, Z. L., \& Anggereini, E. (2016). Pengembangan Edu Komik Sebagai Bahan Ajar Berbasis Pendidikan Karakter Pada Materi Interaksi Mahluk Hidup Dan Lingkungannya Di Sekolah Menengah Pertama. Jurnal Biodik, 2(1), 27-33.

Garcia, A., Kelly, M. R., \& Stamatis, K. (2020). When Technology Goes Unnoticed: Teacher Beliefs And Assumptions About Technology Use In Three 9th Grade English Classrooms. Pedagogies, 1-22. Https://Doi.Org/Https://Doi.Org/10.1080/1554480x.2020.1781638

Harlen, W., \& Qualter, A. (2018). The Teaching Of Science In Primary Schools. Routledge. Https://Books.Google.Co.Id/Books?Id=Rhxtdwaaqbaj

Jamun, Y. M. (2018). Dampak Teknologi Terhadap Pendidikan. Jurnal Pendidikan Dan Kebudayaan Missio, $10(1), 48-52$.

Kang, H. T., \& Noh, S. G. (2017). The Effect On Elementary Science Education Based On Student's PreInquiry. Universal Journal Of Educational Research, 5(9), 1510-1518. Https://Doi.Org/10.13189/Ujer.2017.050908

Kemendiknas. (2010). Bahan Pelatihan Penguatan Metodologi Pembelajaran Berdasarkan Nilai-Nilai Budaya Untuk Membentuk Daya Saing Dan Karakter Bangsa Pengembangan Pendidikan Budaya Dan Karakter Bangsa. Badan Penelitian Dan Pengembangan Pusat Kurikulum.

Kola, M. I. (2017). Technology Teacher Trainees' Lesson Planning Approach In South Africa: Room For Improvement. African Journal Of Research In Mathematics, Science And Technology Education, 21(3), 293-303. 
1261 Analisis Respon Pengguna terhadap Penerapan Web-based Assessment pada Penilaian Sikap Siswa terhadap Mata Pelajaran IPA dan Nilai-nilai Pendidikan Karakter - Febri Tia Aldila, Darmaji, Dwi Agus Kurniawan

DOI: https://doi.org/10.31004/edukatif.v4i1.2091

Kurniawan, D. A., Astalini, A., \& Kurniawan, N. (2019a). Analisis Sikap Siswa Smp Terhadap Mata Pelajaran Ipa. Lentera Pendidikan: Jurnal Ilmu Tarbiyah Dan Keguruan, 22(2), 323-334. Https://Doi.Org/10.24252/Lp.2019v22n2i14

Kurniawan, D. A., Astalini, A., \& Kurniawan, N. (2019b). Sikap Siswa Terhadap Pelajaran Ipa Di Smp Kabupaten Muaro Jambi Provinsi Jambi. Curricula: Journal Of Teaching And Learning, 4(3), 111-127. Https://Doi.Org/10.29303/Jpm.V14i2.1065

Kurniawan, D. A., Astalini, A., Kurniawan, N., \& Pathoni, H. (2019). Analisis Korelasi Sikap Siswa Dan Disiplin Siswa Terhadap Ipa Pada Siswa Smp Provinsi Jambi. Jurnal Pendidikan Fisika Dan Keilmuan (Jpfk), 5(2), 59-71. Https://Doi.Org/10.25273/Jpfk.V5i2.5014

Lin, K. Y., Hsiao, H. S., Williams, P. J., \& Chen, Y. H. (2019). Effects Of 6e-Oriented Stem Practical Activities In Cultivating Middle School Students' Attitudes Toward Technology And Technological Inquiry Ability. Research In Science And Technological Education, 1-18. Https://Doi.Org/Https://Doi.Org/10.1080/02635143.2018.1561432

Liu, X., Li, L., \& Zhang, Z. (2017). Small Group Discussion As A Key Component In Online Assessment Training For Enhanced Student Learning In Web-Based Peer Assessment. Assessment And Evaluation In Higher Education, 1-16. Https://Doi.Org/Http://Dx.Doi.Org/10.1080/02602938.2017.1324018

Maison, M., Kurniawan, D. A., \& Pratiwi, N. I. S. (2020). Pendidikan Sains Di Sekolah Menengah Pertama Perkotaan: Bagaimana Sikap Dan Keaktifan Belajar Siswa Terhadap Sains? Jurnal Inovasi Pendidikan Ipa, 6(2), 135-145. Https://Doi.Org/10.21831/Jipi.V6i2.32425

Mardiana, H. (2020). Lecturers' Adaptability To Technological Change And Its Impact On The Teaching Process. Jpi (Jurnal Pendidikan Indonesia), 9(2), 275-289. Https://Doi.Org/10.23887/JpiUndiksha.V9i2.24595

Pamungkas, A., Subali, B., \& Linuwih, S. (2017). Implementasi Model Pembelajaran Ipa Berbasis Kearifan Lokal Untuk Meningkatkan Kreativitas Dan Hasil Belajar Siswa. Jurnal Inovasi Pendidikan Ipa, 3(2), 118-127. Https://Doi.Org/10.21831/Jipi.V3i2.14562

Permata, S. D., \& Mustadi, A. (2020). Reflective Modul Berbasis Child Friendly School Untuk Meningkatkan Kemampuan Literasi Dan Karakter Siswa. Kuangsan: Jurnal Teknologi Pendidikan, 08(02), 251-274. Https://Doi.Org/Https://Doi.Org/10.31800/Jtp.Kw.V8n2.P251--274 Reflective

Pratama, A. P., \& Buditjahjanto, I. G. P. A. (2016). Pengembangan Media Pembelajaran Berbasis Web (Web Based Learning) Pada Mata Pelajaran Dasar Kompetensi Kejujuran Pada Siswa Kelas Xii Tei , Di Smk Negeri 1 Sukorejo, Pasuruan. Jurnal Pendidikan Teknik Elektro, 5(2), 567-574.

Purnama, E. K. (2015). Peningkatan Sikap Kedisiplinan Siswa Sekolah Dasar Melalui Pemanfaatan Media Audio Pendidikan Karakter. Kuangsan: Jurnal Teknologi Pendidikan, 3(1), 45-58. Https://Doi.Org/Https://Doi.Org/10.31800/Jtp.Kw.V3n1.P45--58

Rockenbach, A. N. (2020). Character Education For The Public Good: The Evolution Of Character Capacities In And Beyond College. Journal Of College And Character, 21(1), 6-13. Https://Doi.Org/10.1080/2194587x.2019.1696834

Sadiqin, I. K., Santoso, U. T., \& Sholahuddin, A. (2017). Pemahaman Konsep Ipa Siswa Smp Melalui Pembelajaran Problem Solving Pada Topik Perubahan Benda-Benda Di Sekitar Kita. Jurnal Inovasi Pendidikan Ipa, 3(1), 52-62. Https://Doi.Org/10.21831/Jipi.V3i1.12554

Suhartini, S., Sekarningrum, B., Sulaeman, M. M., \& Gunawan, W. (2019). Social Construction Of Student Behavior Through Character Education Based On Local Wisdom. Journal Of Social Studies Education Research, 10(3), 276-291.

Suma, K., Suwindra, I. N. ., \& Sujanem, R. (2020). The Effectiveness Of Blended Learning In Increasing Prospective Physics Teacher Students' Learning Motivation And Problem-Solving Ability. Jpi (Jurnal 
1262 Analisis Respon Pengguna terhadap Penerapan Web-based Assessment pada Penilaian Sikap Siswa terhadap Mata Pelajaran IPA dan Nilai-nilai Pendidikan Karakter - Febri Tia Aldila, Darmaji, Dwi Agus Kurniawan

DOI: https://doi.org/10.31004/edukatif.v4i1.2091

Pendidikan Indonesia), 9(3), 436-445. Https://Doi.Org/10.23887/Jpi-Undiksha.V9i3.21947

Susilowati, S. (2017). Pengembangan Bahan Ajar Ipa Terintegrasi Nilai Islam Untuk Meningkatkan Hasil Belajar Ipa. Jurnal Inovasi Pendidikan Ipa, 3(1), 78-88. Https://Doi.Org/10.21831/Jipi.V3i1.13677

Tiara, S. K., \& Sari, E. Y. (2019). Analisis Teknik Penilaian Sikap Sosial Siswa Dalam Penerapan Kurikulum 2013 Di Sdn 1 Watulimo. Eduhumaniora: Jurnal Pendidikan Dasar, 11(1), 21-30. Https://Doi.Org/10.17509/Eh.V11i1.11905

Wang, T. (2011). Developing Web-Based Assessment Strategies For Facilitating Junior High School Students To Perform Self-Regulated Learning In An E-Learning Environment. Computers \& Education, 57(2), 1801-1812. Https://Doi.Org/10.1016/J.Compedu.2011.01.003

Wang, T. H. (2018). Developing A Web-Based Assessment System For Evaluating Examinee's Understanding Of The Procedure Of Scientific Experiments. Eurasia Journal Of Mathematics, Science And Technology Education, 14(5), 1791-1801. Https://Doi.Org/Https://Doi.Org/10.29333/Ejmste/85170

Winda, F. R., Kurniawan, W., \& Darmaji. (2021). Analisis Respon Pengguna Terhadap Penerapan Web-Based Assessment Pada Praktikum Fisika Dasar. Edumaspul: Jurnal Pendidikan, 5(1), 208-215.

Zheng, L., Cui, P., Li, X., \& Huang, R. (2017). Synchronous Discussion Between Assessors And Assessees In Web-Based Peer Assessment: Impact On Writing Performance, Feedback Quality, Meta-Cognitive Awareness And Self-Efficacy. Assessment And Evaluation In Higher Education, 1-15. Https://Doi.Org/Http://Dx.Doi.Org/10.1080/02602938.2017.1370533 